\title{
Thin layer microcolony culture associated with PCR for early identification of Mycobacterium bovis
}

\author{
Tatiana Reis do Rosário ${ }^{1}$, Cristina Corsi Dib ${ }^{2}$, Eliana Roxo ${ }^{2}$, Sônia Regina Pinheiro ${ }^{1}$, \\ Silvio Arruda Vasconcellos ${ }^{1}$, Nilson Roberti Benites ${ }^{1}$ \\ ${ }^{1}$ Faculdade de Medicina Veterinária e Zootecnia, Universidade de São Paulo, São Paulo SP, Brazil. \\ ${ }^{2}$ Laboratório de Tuberculose, Centro de Pesquisa e Desenvolvimento de Sanidade Animal, \\ Instituto Biológico de São Paulo, São Paulo, SP, Brazil.
}

Submitted: December 27, 2012; Approved: April 4, 2013.

\begin{abstract}
The initial growth of mycobacteria from 49 samples of cattle and buffalo organs collected in commercial slaughterhouses was compared between modified Middlebrook 7H11 thin layer microcolony culture and Stonebrink medium used in the isolation of Mycobacterium bovis. Aliquots were decontaminated by Petroff's method, processed and cultured in both media. The identity of the acid-fast bacilli stained by Ziehl-Neelsen was confirmed by PCR. Optical microscopy showed that results of the early observation of Mycobacterium bovis colonies in thin layer culture were similar to those obtained in macroscopic observation of the colonies in Stonebrink medium. However, early observation of the colonies enabled early confirmation by PCR, given the shorter time to the visualization of colonies when thin layer culture was used (between the $12^{\text {nd }}$ and $25^{\text {th }}$ day of culture).
\end{abstract}

Key words: tuberculosis, Mycobacterium bovis, thin layer, PCR, cattle and buffalo organs.

\section{Introduction}

Bovine tuberculosis is caused by an intracellular pathogen, an acid-fast bacillus (AFB) in the M. bovis species. It causes a chronic disease that affect the well-being and productivity of the animals, leading to significant economic losses, and posing public health problems in some countries (Pollock et al., 2005).

Mycobacterium bovis culture in conventional Stonebrink medium remains the gold standard for the detection of M. tuberculosis complex in clinical samples of cattle tissue, nasal discharges, milk, blood, and environmental samples (Rua-Domenech et al., 2006). M. bovis, particularly, has difficulty in growing in glycerinated media, and grows better in Stonebrink, an egg-based medium in which glycerol is replaced by sodium pyruvate (Grange et al., 2010; O'Reilly and Daborn, 1995). However, growth may still take, in average, from 24 to 40 days to be visible, making diagnosis difficult (Koneman et al., 2001).

In an attempt to perfect traditional microbiological methods, researchers have investigated the efficiency of clear media in thin layer culture, such as Middlebrook $7 \mathrm{H} 11$. These media enable the visualization of initial growth stages microcolonies and preliminary identification of mycobacteria by morphological characteristics of the colonies (Dib et al., 2006; Marcondes et al., 2006; Mejía et al., 1999; Robledo et al., 2006; Silva et al., 2007).

In order to confirm the identity of the isolates for $M$. bovis, the use of molecular methods has replaced classical bacteriological techniques (Roring et al., 2000; Zanini et al., 2001), enabling faster decision-making in the control of the disease in men and animals, and enabling immediate intervention in herds.

Given the importance of the topic and the time required to isolation of mycobacteria in clinical samples, the present study was designed to investigate the use of the association between modified Middlebrook 7H11 medium thin layer culture and Polymerase Chain Reaction (PCR) to identify Mycobacterium bovis in cattle and buffalo organs obtained in commercial slaughterhouses.

Send correspondence to T.R. Rosário. Faculdade de Medicina Veterinária e Zootecnia, Universidade de São Paulo, Av. Prof. Dr. Orlando Marques de Paiva 87, 05508-270 São Paulo, SP, Brazil. E-mail: tatianareis@yahoo.com.br. 


\section{Material and Methods}

A total of 49 samples of cattle and buffalo organs were collected in commercial slaughterhouses (21 lymph nodes, one uterus, one spleen, one kidney, two livers, three lungs, and ten samples of different organs). Thirty nine samples came from animals with lesions suggestive of tuberculosis, and 10 samples of lymph nodes of animals approved by meat inspectors were used as negative controls.

Isolation was carried out in Stonebrink medium and modified Middlebrook 7H11 medium (Universidad de las Naciones Unidas, 1998).

Stonebrink medium was placed in test tubes $(18 \mathrm{x}$ $180 \mathrm{~mm}$ ) with hydrophobic cotton stoppers, $7.0 \mathrm{~mL}$ per tube. After the inoculum was placed in the tubes, the mouth of the tube was warmed by flaming and closed with cork stopper. Modified Middlebrook 7H11 medium was pre- pared with sodium pyruvate as the carbon source to replace glycerol, and was distributed in plastic Petri dishes $(60 \mathrm{x}$ $16 \mathrm{~mm}), 10 \mathrm{~mL}$ per plate.

Organs were decontaminated by Petroff's classic method (Kantor, 1988), and cultured in duplicate in both media to avoid losses by sample contamination. Cultures were incubated at $37^{\circ} \mathrm{C}$, and thin layer plates were placed in a $\mathrm{CO}_{2}$ atmosphere (Dib et al., 2006; Marcondes et al., 2006; Mejía et al., 1999; Robledo et al., 2006; Silva et al., 2007).

Plates were read on days 5, 8, 12, 15, 18, 21, 29, and 36 post-culture (p.c.) by conventional microscope at $100 \mathrm{x}$ magnification. Plates were considered positive when they showed micro and / or macroscopic characteristic growth of AFB in this medium: rough aspect, irregular borders, brown color, and serpentine cords (Figure 1). On the other hand, negative plates were those in which no growth was

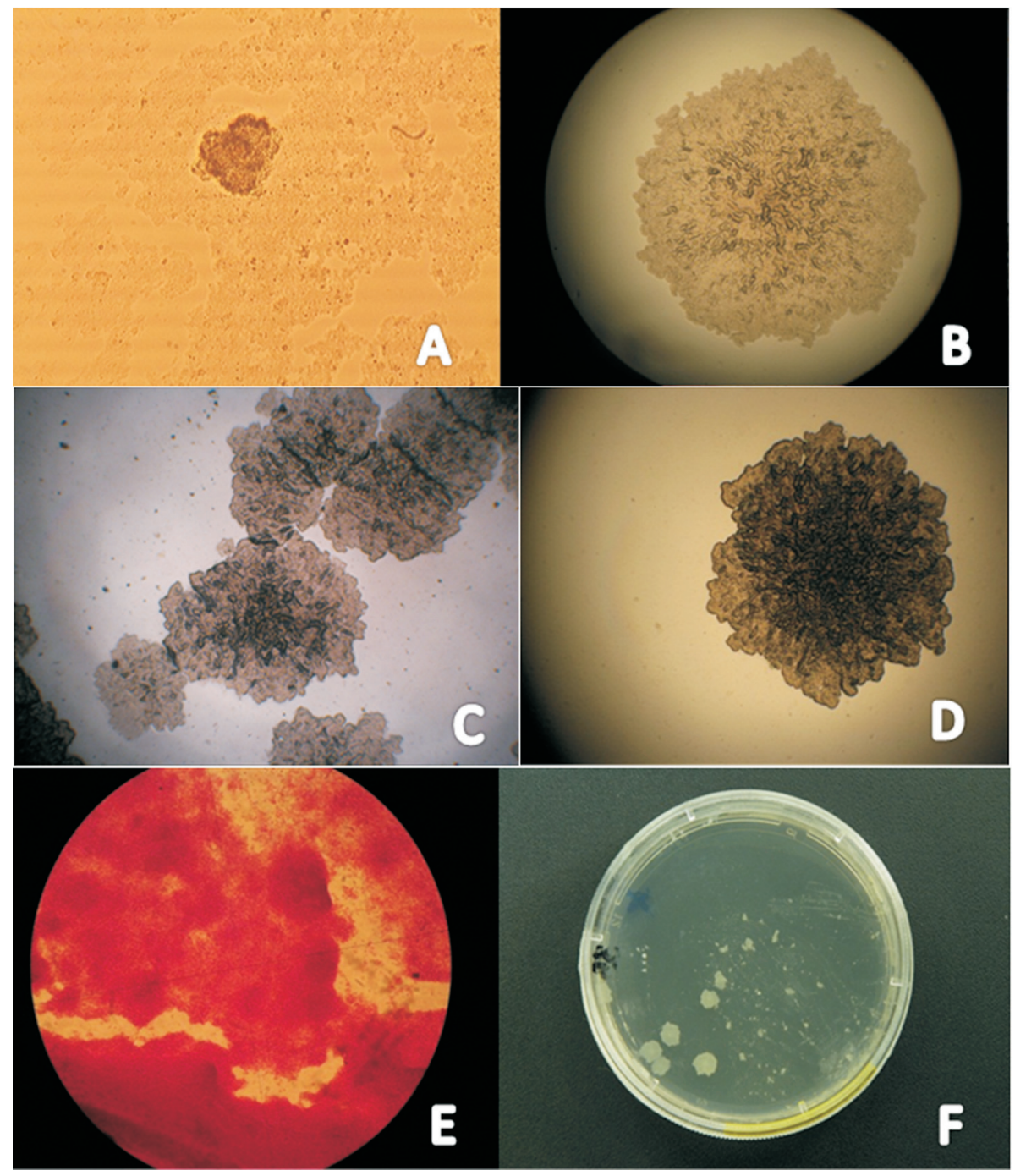

Figure 1 - Mycobacterium bovis colonies isolated in modified Middlebrook 7H11 medium thin layer culture showing the microscopic and macroscopic growth phases with Ziehl-Neelsen stain. A) Colony on day 12, 100x magnification. B) Colony on day 15, 100x magnification. C) Colony on day 21, 100x magnification. D) Colony on day 25, 40x magnification. E) Ziehl-Neelsen stain showing acid-fast microorganisms, 400x magnification. F) Petri dish showing colonies on day 37 p.c. 
observed. Stonebrink tubes were read every week, and reading was stopped by the $12^{\text {th }}$ week p.c.

Colonies isolated in plates and tubes were stained by Ziehl-Neelsen (Idigoras et al., 1995) for microscopic observation of AFB. PCR material was harvested with a sterile loop, scraping the medium surface plates and tubes where no colony growth was visualized. Polymerase chain reaction (PCR) was carried out by suspending isolated colonies in ultrapure sterile water in $1.5-\mathrm{mL}$ microtubes. Bacilli were inactivated by boiling at $100^{\circ} \mathrm{C}$ for five minutes, and were then frozen at $-20{ }^{\circ} \mathrm{C}$ for at least one hour (BemerMelchior and Drugeon, 1999).

Isolated colonies were submitted to PCR with primers JB-21 (5' TCGTCCGCTGATGCAAGTGC 3') and JB-22 (5' CGTCCGCTGACCTCAAGAAG 3'), described by Rodriguez et al. (1995), modified by Harakava et al. (2010) for the identification of Mycobacterium bovis.

DNA amplification was carried out with an initial treatment at $94{ }^{\circ} \mathrm{C}$ for two minutes, followed by 35 cycles of denaturation at $94{ }^{\circ} \mathrm{C}$ for 30 seconds, hybridization at $64{ }^{\circ} \mathrm{C}$ for 30 seconds, and extension and annealing at $72{ }^{\circ} \mathrm{C}$ for 60 seconds. After the last cycle, samples were maintained at $72{ }^{\circ} \mathrm{C}$ for five minutes, and the amplified product was analyzed by electrophoresis in a horizontal gel. Agarose gels $1.5 \%$ containing ethidium bromide $0.01 \%$ were analyzed under UV light and photographed for the observation of the final product with 500 base pairs (Harakava et al., 2010).

Statistical analysis was carried out using McNemar test in GRAPHPAD INSTAT 1990-93.

\section{Results}

The control group did not show growth in any of the plates or tubes, confirming that the samples were negative. PCR was not carried out in these samples.

From the 39 samples with tuberculosis diagnosis given by meat inspectors, $17(43.59 \%)$ were considered positive in modified Middlebrook $7 \mathrm{H} 11$ medium. In five of these samples, growth was observed in only one plate. When the same samples were cultured in Stonebrink tubes, $18(46.15 \%)$ showed to be positive, and growth was observed in only one tube in six samples.

When the negative control and the test samples were compared together in terms of the performance in thin layer culture and Stonebrink tubes, 13 samples $(23.56 \%)$ were positive and $27(23.56 \%)$ were negative in both tests. Kappa agreement was 0.82 . On the other hand, four samples negative in Stonebrink medium were positive in thin layer culture, whereas five samples positive in Stonebrink medium were negative in thin layer culture (Table 1). Statistical analysis showed that thin layer culture had relative sensitivity of $72.22 \%$, and relative specificity of $87.09 \%$ compared with Stonebrink medium.

Results related to time to visible growth or absence of mycobacteria in thin layer culture showed that from the 17
Table 1 - Performance of modified Middlebrook 7H11 medium thin layer culture compared with Stonebrink medium.

\begin{tabular}{lcc}
\hline & \multicolumn{2}{c}{ Stonebrink (gold standard) } \\
\cline { 2 - 3 } Thin layer (test) & Positive & Negative \\
\hline Positive & 13 & 4 \\
Negative & 5 & 27 \\
Total & 18 & 31 \\
\hline
\end{tabular}

Relative sensitivity: $13 / 18=72.22 \%$.

Relative specificity: $27 / 31=87.09 \%$.

samples positive in the plates, four (23.52\%) were positive on day 12 p.c., nine (52.94\%) on day 15 p.c., fourteen $(82.35 \%)$ on day 21 p.c., and $17(100 \%)$ on day 25 p.c. Thus, more than $50 \%$ of the positive results were found on day 15 p.c., and from the $25^{\text {th }}$ day on, no more new growth was observed. From the $25^{\text {th }}$ to the $36^{\text {th }}$ day p.c., some plates showed such pronounced growth that it became difficult to read them at 100x magnification. These plates were read at 40x magnification.

In thin layer culture on day 12 p.c., the four positive results were considered significant $(p=0.0455)$ when compared with Stonebrink medium. Consequently, positive results accumulated on days $15(\mathrm{p}=0.001), 21(\mathrm{p}=0.001)$ and $25(\mathrm{p}=0.001)$ p.c. were all significant compared with those obtained with Stonebrink medium. Thin layer culture enabled early observation of colony growth from clinical samples starting on day 12 .

From the 18 samples positive for M. bovis in Stonebrink medium, seven $(38.89 \%)$ were positive in the $6^{\text {th }}$ week p.c.; $10(55.55 \%)$ in the $7^{\text {th }}$ week p.c.; $12(66.67 \%)$ in the $8^{\text {th }}$ week p.c.; $14(77.78 \%)$ in the $9^{\text {th }}$ and $10^{\text {th }}$ week p.c.; $16(88.89 \%)$ in the $11^{\text {th }}$ week p.c.; $17(94.44 \%)$ in the $12^{\text {th }}$ week p.c.; and $18(100 \%)$ in the $13^{\text {th }}$ week p.c. Thus, more than $50 \%$ of the positive results were observed in the $7^{\text {th }}$ week p.c., and growth was observed until the $89^{\text {th }}$ day $\left(13^{\text {th }}\right.$ week). Growth was not observed until the $5^{\text {th }}$ week (35 days), or in the $10^{\text {th }}$ week (70 days).

PCR was positive in 17 samples from thin layer culture, and two plates showed no visible growth. From the 18 colonies isolated in Stonebrink medium, 17 were amplified in PCR.

Slides observed in the microscope (400x magnification) showed the presence of acid-fast microorganisms with unusual characteristics (coccoid shape, with little or no bacillus shape or serpentine cords), when compared with the traditional description of AFB. Only after the confirmation of the positive results for these samples in PCR, associated with the characteristics of the colonies in the thin layer culture (rough aspect, irregular borders, brown color), the isolates were considered to be M. bovis (Box 1). 


\section{Discussion}

PCR carried out straight from the clinical samples shows restrictions in terms of sensitivity, mainly in the detection of M. bovis in paucibacillary samples. In these samples, culture shows greater sensitivity (Collins et al., 1994; Roring et al., 2000; Ruggiero et al., 2007). Although several researchers have been trying to determine protocols for mycobacterial DNA extraction from clinical samples using commercial kits or organic solvents, results are still very irregular (Roring et al., 2000). Therefore, in the present study, PCR was only carried out using DNA extracted from colonies isolated in culture media.

Modified Middlebrook 7H11 medium has the advantage of being transparent, enabling direct observation of the plates in the microscope. The use of thin layer plates contributes for the early observation of mycobacterial growth. Durmaz et al. (1985), Idigoras et al. (1995), and Mejía et al. (1999), working with diagnosis of mycobacteria from the M. tuberculosis complex reported the advantage of anticipating the results by early observation of microcolonies in Middlebrook 7H11 medium. Marcondes (2002) emphasized that Middlebrook 7H11 medium does not increase the speed of colony growth, but as it is transparent, plates may be placed directly in the microscope, and colonies may be visualized in initial stages of growth.

Marcondes et al. (2006), working with $5 \mathrm{~mL}$ of Middlebrook 7H11 medium in glass Petri dishes $(60 \times 16 \mathrm{~mm})$, observed that the medium was viable for only two weeks. After that, it became dry. In order to enable colony observation for up to 36 days, the present study used $10 \mathrm{~mL}$ of Middlebrook medium per $60 \times 16 \mathrm{~mm}$ plates, preventing the medium from getting dry. As also observed by Dib et al. (2006), Marcondes et al. (2006) and Morato et al. (2009), some plates showed contamination in some points of medium surface, but this secondary growth did not affect reading or mycobacterial growth.

Results of the present study are similar to those reported by Durmaz et al. (1985), who worked with Middlebrook 7H11 medium thin layer culture and isolated $M$. tuberculosis after 10 days of culture, without any isolation in Löweinstein-Jensen (L-J) medium. Idigoras et al. (1995) isolated mycobacteria in Middlebrook 7H11 medium thin layer culture at 12 days p.c., compared with 23 days, in average, for colony visualization in L-J. Mejía et al. (1999) also compared Middlebrook 7H11 with L-J and detected, among positive samples, that $60 \%$ of them showed growth at 10 days p.c., while there was no growth in L-J; and that $80 \%$ of these positive samples showed growth after two weeks, while growth was seen in L-J medium in only $10 \%$ of them.

When the total of 18 positive samples (in tubes or plates) was compared, four were positive only in thin layer plates, and five only in Stonebrink medium. In this case, the possible explanation for this disagreement is that in paucibacillary samples, the decontamination process by Petroff can cause a further decrease in the number of viable bacilli, due to injuries to microorganism that hamper their survival in the culture medium. Thus, even with homogenization, during simultaneous culture, the small amount of viable microorganism contained in the inoculum may have caused the observed differences in the results, due to difficult in their adaptation and survival in the mediums and conditions of microaerofilias in each case, justifying the use of two tubes and two plates per samples. Liu et al. (1973) found the lowest isolation rate of mycobacteria in Middlebrook 7H10 medium compared with other media, but they considered that this may have been caused by not using a microaerophilic environment, which was used in both media in the present study.

Although colonies were visible in Stonebrink medium since the $6^{\text {th }}$ week of culture, positive results in thin layer plates were over on day 36 p.c. Culture in Stonebrink medium still is the gold standard for the isolation of mycobacteria from clinical samples (Kantor, 1988). Therefore, the use of rapid methods should be considered to support situations in which quick decision-making is necessary to respond to an outbreak in a herd, or to confirm findings of meat inspectors. The National Program for Brucellosis and Tuberculosis Control and Eradication recommends the isolation and identification of $M$. bovis to confirm lesions suggestive of the disease in the slaughter of cattle and buffaloes. Thus, the association of quick methods for isolation and PCR may be a way to anticipate results, while waiting for results of the standard culture in Stonebrink medium.

Considering the results of the plates, PCR confirmed as positive not only the 17 samples that showed growth, but also the two that were negative, in a total of 19 positive results. It is possible that these samples that were negative in thin layer culture presented microscopic colonies that were enough to produce a positive PCR result.

As for Stonebrink culture, PCR confirmed as positive 17 of the 18 samples. One of the tubes that were considered positive in visual analysis had orange colonies, and showed to be negative in PCR. This tube possibly had environmental mycobacteria instead of M. bovis.

In spite of the recent development of different bacteriological methods for tuberculosis diagnosis, none of them should be used alone (Cosivi et al., 1998). Ruggiero et al. (2007) also reinforced the need to associate different techniques to obtain complete information. These authors emphasized that laboratory results should be associated with other findings, such as tuberculin test, post-mortem examination, histological methods, and PCR, among others.

Rodriguez et al. (1995) described the first primers JB21 and JB22, initially considered specific for M. bovis. However, after amplification, it was observed that they also amplified at least $25 \%$ of the M. tuberculosis isolates (Ruggiero et al., 2007). In the present study, it was considered that positive samples in PCR were M. bovis, once $M$. 
tuberculosis is much less likely to be responsible for the lesions in the organs sampled. However, this finding could only be confirmed by classical microbiological methods and complementary molecular techniques.

Changes in the morphology of the microorganisms observed in the present study may be explained by the fact that colonies obtained in modified Middlebrook 7H11 synthetic medium may have been dysgonic, when compared with those obtained in Stonebrink medium, rich in organic material (egg yolk). Trabulsi (1999) observed that mycobacteria are slow-growing microorganisms with approximate generation time of 12 hours. This difficulty in growing may be related to the slower absorption of nutrients, probably caused by the large amount of lipids in the bacterium wall. Thus, early observation with the end of reading after the $36^{\text {th }}$ day p.c. may have led to the stagnation of mycobacterial growth, preventing these bacteria from assuming their classic bacillus shape, and showing a coccoid shape. Besides, the fact that Nocardia are generally acidfast and may have coccoid shape (Trabulsi, 1999), reinforce the importance of $M$. bovis confirmation by PCR, to remove any doubts about the findings in the slides.

The Middlebrook 7H11 modified thin layer was about 17 times more expensive compared to Stonebrink medium due to the OADC enrichment, required for the growth of $M$. bovis. However, the advantage of getting an early diagnosis allows greater flexibility in the application of sanitary measures required, after the identification of focus, thereby interrupting the transmission of the disease in the herd or region and avoiding major damage to animal and human health. The development of research using other sources of enrichment for this medium, could reduce costs by making feasible the use of this technique in laboratories with limited financial resources, due to the ease of preparation, distribution and conservation of the plates, and the short time required for training visual identification of the colonies.

Despite the increasing use of molecular methods that aim to reduce the time of diagnosis of bovine tuberculosis, the microorganism isolation is an important tool in the confirmatory diagnosis. The isolated mycobacteria can also be used in later studies for molecular epidemiology and contribute to understanding the dynamics of distribution and spread of bovine tuberculosis among hosts.

\section{Conclusions}

Mycobacterium bovis from samples of cattle and buffalo organs cultured in thin layer modified Middlebrook 7H11 medium showed to be viable compared with classic culture in Stonebrink medium. This technique may be used as a complement to traditional methods of diagnosis of bovine tuberculosis. Growth of mycobacteria was identified earlier in thin layer culture (between the $12^{\text {th }}$ to $25^{\text {th }}$ day of culture) than in Stonebrink medium (from the $42^{\text {nd }}$ to the $91^{\text {st }}$ day of culture). The association with PCR as way to confirm results observed in thin layer culture was also viable.

\section{References}

Bemer-Melchior P, Drugeon HB (1999) Inactivation of Mycobacterium tuberculosis for DNA Typing Analysis. J Clin Microbiol 37:2350-2351.

Collins DM, Radford AJ, De Lisle GW, Billman-Jacobe H (1994) Diagnosis and epidemiology of bovine tuberculosis using molecular biological approaches. Vet Microbiol 40:83-94.

Cosivi O, Granje JM, Daborn CJ, Raviglione MC, Fugikura T, Cousins D, Robinson RA, Huchzermeyer HFAK, Kantor I, Meslin FX (1998) Zoonotic tuberculosis due to Mycobacterium bovis in developing countries. Emerg Infect Dis 4:5970.

Dib CC, Morais ZM, Souza GO, Amaku M, Benites NR, Pinheiro SR (2006) Utilização de uma técnica rápida para o diagnóstico de Mycobacterium bovis em amostras de leite experimentalmente inoculadas. Arq Inst Biol 73:149-155.

Durmaz R, Durmaz B, Gürel M (1985) Mycobacterium tuberculosis cultures in Mycobacterium 7H11 agar vs. LöwensteinJensen medium. Bull Microbiol 19:88-94.

Grange JM, Yates MD, Kantor IN (2010) Guidelines for speciation within the Mycobacterium tuberculosis complex. $2^{\text {nd }}$ ed [homepage on the internet]. World Health Organization WHO/EMC/ZOO 96.4 [cited 2010 jun 30]. Available from: http://whqlibdoc.who.int/hq/1996/WHO_EMC_ZOO_96.4 .pdf.

Harakava R, Ikuno AA, Baldassi L, Roxo E (2010) Identificação de Mycobacterium bovis: otimização da reação de PCR com os primers JB21 e JB22. Seminário Nacional sobre Brucelose e Tuberculose Animal, 2010, Belo Horizonte, MG.

Idigoras P, Pérez-Trallero E, Alcorta M, Gutiérrez C, MuñozBaroja I (1995) Rapid detection of tuberculous and nontuberculous mycobacteria by microscopic observation of growth on Middlebrook 7H11 agar. Eur J Clin Microbiol Infect Dis 14:6-10.

Kantor IN (1988) Centro Panamericano de Zoonosis. Bacteriología de la tuberculosis humana y animal. Organización Panamericana de la Salud (Serie de Monografías Científicas y Técnicas; 11 rev.1), Buenos Aires, 63 pp.

Koneman EW, Allen SD, Landa WM, Schreckenberger PC, Winn Junior WC (2001) Diagnóstico microbiológico. Texto e Atlas colorido, 5 ed., Editora Medsi, Rio de Janeiro, 1465 pp.

Liu PI, Mcgregor DH, Faucher I, Jinks WI, Miller LA, Green L, Liu JG (1973) Comparison of three culture media for isolation of Mycobacterium tuberculosis: a 6-year study. Appl Microbiol 26:880-883.

Marcondes AG (2002) Padronização da técnica de cultivo em camada delgada de ágar Middlebrook $7 H 11$ para isolamento de Mycobacterium bovis. São Paulo, Brasil, 113 pp. (M.Sc. Dissertation, Faculdade de Medicina Veterinária e Zootecnia. USP).

Marcondes AG, Shikama MLM, Vasconcellos SA, Benites NR, Morais ZM, Roxo E, Dias RA, Leão SLPC, Pinheiro SR (2006) Comparação entre a técnica de cultivo em camada delgada de ágar Middlebrook 7H11 e meio de Stonebrink para isolamento de Mycobacterium bovis em amostras de campo. Braz J Vet Res Anim Sci 43:362-369. 
Mejía GI, Castrillon H, Trujillo JA, Robledo JA (1999) Microcolony detection in $7 \mathrm{H} 11$ thin layer culture is an alternative for rapid diagnosis of Mycobacterium tuberculosis infection. Int J Tubercul Lung Dis 3:138-142.

Morato F (2007) Avaliação da atividade micobactericida de desinfetantes químicos utilizando a técnica de cultivo em camada de ágar Middlebrook 7H11. São Paulo, Brasil, 87 p. (M.Sc. Dissertation. Faculdade de Medicina Veterinária e Zootecnia. USP).

Morato F, Dias RA, Gonçales AP, Souza GO, Pereira JJ, Pinheiro SR (2009) Utilização de uma técnica rápida em camada delgada para avaliação da atividade micobactericida de desinfetantes químicos. Arq Inst Biol 76:1-7.

O'Reilly LM, Daborn CJ (1995) The epidemiology of Mycobacterium bovis infections in animals and man: a review. Tuber Lung Dis 76: 1-46.

Pollock JM, Welsh MD, McNair J (2005) Immune responses in bovine tuberculosis: towards new strategies for the diagnosis and control of disease. Vet Immunol Immunopathol 108:37-43.

Robledo JA, Mejía GI, Morcillo N, Chacón L, Camacho M, Luna J, Zurita J, Bodon A, Velasco M, Palomino JC, Martin A, Portaels F (2006) Evaluation of a rapid culture method for tuberculosis diagnosis: a Latin American multi-center study. Int J Tuber Lung Dis 10:613-619.

Rodriguez JG, Mejia GI, Del Portillo P, Patarroyo ME, Murillo LA (1995) Species-specific identification of Mycobacterium bovis by PCR. Microbiology 141:2131-2138.

Roring S, Hughes MS, Skuce RA, Neill SD (2000) Simultaneous detection and strain differentiation of Mycobacterium bovis directly from bovine tissue specimens by spoligotyping. Vet Microbiol 74:227-236.

Rua-Domenech R, Goodchild AT, Vordermeier HM, Hewinson RG, Christiansen KH, Clifton-Hadley RS (2006) Ante mortem diagnosis of tuberculosis in cattle: A review of the tuberculin tests, $\gamma$-interferon assay and other ancillary diagnostic techniques. Res Vet Sci 81:190-210.

Ruggiero AP, Ikuno AA, Ferreira VCA, Roxo E (2007) Tuberculose bovina: alternativas para o diagnóstico. Arq Inst Biol 74:55-65.

Silva PEA, Wiesel F, Boffo MMS, Von Groll A, Mattos IG, Mejía G, Robledo J (2007) Microcolony detection in thin layer culture as an alternative method for rapid detection of Mycobacterium tuberculosis in clinical samples. Braz J Microbiol 38:421-423.

Trabulsi LR (1999) Microbiologia, 3rd ed, Atheneu, São Paulo, $720 \mathrm{pp}$.

Universidad de las Naciones Unidas (1998) Programa de biotecnología para Latinoamérica y el Caribe - BIOLAC. Red Latinoamericana y del Caribe de tuberculosis - RELACTB. Nuevas tecnologías para el diagnóstico y pruebas de susceptibilidad a drogas de $M$. tuberculosis para países en vías de desarrollo. UNU, La Paz, Bolivia, p. 18-21.

Zanini MS, Moreira EC, Lopes MTP, Oliveira RS, Leão SC, Fioravanti RL, Roxo E, Zumárraga M, Romano MI, Cataldi A, Salas CE (2001) Mycobacterium bovis: polymerase chain reaction identification in bovine lymph node biopsies and genotyping in isolates from southeast Brazil by spoligotyping and restriction fragment length polymorphism. Mem Inst Oswaldo Cruz 96:2809-2813.

All the content of the journal, except where otherwise noted, is licensed under a Creative Commons License CC BY-NC. 